\title{
A Rhesus Monkey Model to Characterize the Role of Gastrin-releasing Peptide (GRP) in Lung Development Evidence for Stimulation of Airway Growth
}

Kang Li, Srinivasa R. Nagalla, and Eliot R. Spindel

Division of Neuroscience, Oregon Regional Primate Research Center, Beaverton, Oregon 97006

\begin{abstract}
Gastrin-releasing peptide (GRP) is developmentally expressed in human fetal lung and is a growth factor for normal and neoplastic lung but its role in normal lung development has yet to be clearly defined. In this study we have characterized the expression of GRP and its receptor in fetal rhesus monkey lung and determined the effects of bombesin on fetal lung development in vitro. By RNA blot analysis, GRP mRNA was first detectable in fetal monkey lung at 63 days gestation, reached highest levels at 80 days gestation, and then declined to near adult levels by 120 days gestation; a pattern closely paralleling GRP expression in human fetal lung. As in human lung, in situ hybridization localized GRP mRNA to neuroendocrine cells though during the canalicular phase of development (between 63-80 days gestation) GRP mRNA was present not only in classic pulmonary neuroendocrine cells, but also in cells of budding airways. Immunohistochemistry showed that bombesin-like immunoreactivity was present in neuroendocrine cells, but not in budding airways, suggesting that in budding airways either the GRP mRNA is not translated, is rapidly secreted, or a related, but different RNA is present. RNase protection analysis using a probe to the monkey GRP receptor demonstrated that the time course of receptor RNA expression closely paralleled the time course of GRP RNA expression. In situ hybridization showed that GRP receptors were primarily expressed in epithelial cells of the developing airways. Thus GRP would appear to be secreted from neuroendocrine cells to act on target cells in developing airways. This hypothesis was confirmed by organ culture of fetal monkey lung in the presence of bombesin and bombesin antagonists. Bombesin treatment at 1 and $10 \mathrm{nM}$ significantly increased DNA synthesis in airway epithelial cells and significantly increased the number and size of airways in cultured fetal lung. In fact, culturing $60 \mathrm{~d}$ fetal lung for $5 \mathrm{~d}$ with $10 \mathrm{nM}$ bombesin increased airway size and number nearly to that observed in cultured $80 \mathrm{~d}$ fetal lung. The effects of bombesin could be blocked by specific GRP receptor antagonists. Thus this study demonstrates that GRP receptors are expressed on
\end{abstract}

Address correspondence to Eliot R. Spindel, Division of Neuroscience, Oregon Regional Primate Research Center, 505 NW 185th Avenue, Beaverton, OR 97006.

Received for publication 22 September 1993 and in revised form 27 June 1994.

J. Clin. Invest.

(c) The American Society for Clinical Investigation, Inc.

0021-9738/94/10/1605/11 $\$ 2.00$

Volume 94, October 1994, 1605-1615 airway epithelial cells in developing fetal lung and that the interaction of GRP with the GRP receptor stimulates airway development. (J. Clin. Invest. 1994. 94:1605-1615.) Key words: bombesin • fetal lung • growth factors • airway

\section{Introduction}

Bombesin is a tetradecapeptide initially purified from the skin of the frog Bombina bombina in 1971 (1). One mammalian homolog of bombesin is the 27-amino acid peptide, gastrinreleasing peptide (GRP), ${ }^{1}$ initially isolated from porcine stomach by McDonald et al. in 1979 (2). 9 of the $10 \mathrm{COOH}$-terminal amino acids of bombesin and GRP are identical, and this COOH-terminal decapeptide (designated GRP-10) (3) appears to contain full receptor-binding and biological activities. Bombesin and GRP have nearly identical potencies and physiologic effects (4-6), and thus amphibian bombesin is frequently used to study the effects of GRP.

GRP is widely distributed in brain, gastrointestinal tract, and lung, and functions as a neurotransmitter, paracrine hormone, and growth factor (7-9). In the lung, GRP is located in the pulmonary neuroendocrine cells (PNEC) (10), and high levels are found in human fetal and neonatal lung (11-14), and in small cell lung carcinoma (SCLC) $(15,16)$. Peak GRP mRNA expression occurs from 14 to 30 wk gestation and while GRP peptide and mRNA consistently colocalize in neuroendocrine cells in early gestation, by late gestation, many cells that contain GRP peptide no longer contain GRP mRNA (17).

GRP and bombesin have been shown to stimulate the clonal growth of normal bronchial epithelial cells and the growth of SCLC cells both in vitro and in vivo $(6,18-20)$. Cuttitta et al. (18) have demonstrated that antibodies to bombesin can inhibit the growth of SCLC lines in vitro and in vivo and have suggested that GRP is an autocrine growth factor for SCLC. The ability of GRP to stimulate the growth of SCLC cell lines correlates with the expression of the GRP-preferring bombesin receptor subtype. The GRP receptor has been cloned and shown to belong to the seven-membrane spanning domain superfamily (21-23). Specific antagonists of the GRP receptor (GRP-R) have been developed (24) and can inhibit growth of SCLC cell lines that express GRP receptors $(25,26)$. Although the presence of GRP-R in SCLC is well documented, the location, time course and expression of GRP-R in normal fetal lung has yet to be clearly demonstrated.

The observation of peak expression of GRP mRNA in human fetal lung at midgestation (17), combined with growth-

1. Abbreviations used in this paper: GRP, gastrin-releasing peptide; GRP-R, GRP receptor; PNEC, pulmonary neuroendocrine cells; SCLC, small cell lung carcinoma. 
promoting effects on some SCLC cell lines $(18,19,27)$ and pulmonary epithelial cells $(6,20)$, are highly suggestive that GRP gene activation plays a role in normal fetal lung growth. In the mouse, Sunday et al. and King et al. $(28,29)$ have demonstrated that bombesin can stimulate DNA and saturated phosphatidylcholine (SPC) synthesis in fetal lung. Similarly, Aguayo et al. (30) have also demonstrated that bombesin can stimulate airway branching in mouse lung explants. However, it is noteworthy that the GRP is expressed relatively later in gestation in mice than in humans $(17,28)$, and that in contrast to humans, GRP immunoreactivity cannot be localized to mouse PNEC (31). Thus an animal model that more closely parallels human patterns of fetal pulmonary GRP expression is needed to characterize the role of GRP in human lung development. In this paper we demonstrate that the pattern of GRP expression in fetal rhesus (Macaca mulatta) monkey lung closely parallels that of human fetal lung and demonstrate that bombesin and GRP significantly increase both the number and size of small airways in organ cultures of fetal monkey lung.

\section{Methods}

Lung tissues were collected from fetal (50-154 d gestation), neonatal and adult rhesus monkeys. For mRNA measurement, tissues were frozen on liquid nitrogen and stored at $-80^{\circ} \mathrm{C}$. For immunohistochemistry, tissue were fixed in Zamboni's fixative (1.5\% paraformaldehyde and $1 \%$ picric acid) and for in situ hybridization, tissues were fixed in $4 \%$ paraformaldehyde in borate buffer, $\mathrm{pH} 9.5,(32)$.

Generation of specific monkey GRP and GRP receptor $c R N A$ probes. PCR was used to generate specific monkey GRP and GRP-R cDNA probes. Primers corresponding to the beginning and end of the human GRP exon-3 (33) and GRP-R gene exon-3 $(23,34)$ were used to amplify 250-bp fragments of DNA from monkey genomic DNA. Primers chosen for amplification were highly conserved between rat and human (34, 35 ) and thus were likely conserved between human and monkey. The amplified DNA was subcloned into the vector PCR 1000 (Invitrogen, San Diego, CA) and their identity confirmed by DNA sequence analysis. ${ }^{32}$ P-labeled antisense GRP and GRP-R cRNA probes were prepared by transcribing with T7 RNA polymerase as described by Melton et al. (36).

mRNA determination. Total RNA was prepared by the method of Chirgwin et al. (37) by homogenization of lung tissue in guanidinium thiocyanate followed by centrifugation through $\mathrm{CsCl}$. Total RNA was subjected to electrophoresis through $1.5 \%$ formaldehyde-agarose gels and transferred to Duralon nylon membranes (Stratagene, La Jolla, CA) by capillary blotting, and UV-crosslinked (38). Gels were stained with ethidium bromide to visualize the $28 \mathrm{~S}$ and $18 \mathrm{~S}$ ribosomal RNA bands to check for degradation and recovery of RNA. Hybridization was in $5 \times$ SSC; $5 \times$ Denhardt's solution $(1 \times$ Denhardt's solution $=0.02 \%$ Ficoll- $400,0.02 \%$ bovine serum albumin, $0.02 \%$ polyvinylpyrrolidone40 ); $50 \%$ formamide; $50 \mathrm{mM}$ sodium phosphate, $\mathrm{pH} 7.0 ; 0.2 \%$ SDS and sonicated, denatured salmon sperm DNA $(200 \mu \mathrm{g} / \mathrm{ml})$ at $65^{\circ} \mathrm{C}$ for $18 \mathrm{~h}$. Membranes were washed for $2 \times 15 \mathrm{~min}$ in $2 \times \mathrm{SSC} / 0.1 \%$ SDS at room temperature followed by $2 \times 15 \mathrm{~min}$ washes in $0.1 \times \mathrm{SSC} /$ $0.1 \%$ SDS at $65^{\circ} \mathrm{C}$, and exposed for $24-72 \mathrm{~h}$ at $-85^{\circ} \mathrm{C}$ with Kodak XAR films with intensifying screens.

RNase protection assay. RNase protection analysis of the expression of GRP-R mRNA in rhesus monkey lung was performed as described by Ausubel et al. (38). Total RNAs from fetal and adult monkey lungs were hybridized with gel purified, ${ }^{32} \mathrm{P}$-labeled GRP-R cRNA probe in hybridization buffer ( $40 \mathrm{mM}$ Pipes, pH $6.4 ; 0.4 \mathrm{M} \mathrm{NaCl} ; 1 \mathrm{mM}$ EDTA; $80 \%$ formamide ) at $45^{\circ} \mathrm{C}$ for $18 \mathrm{~h}$, digested with $40 \mu \mathrm{g} / \mathrm{ml}$ ribonuclease A and $2 \mu \mathrm{g} / \mathrm{ml}$ ribonuclease $\mathrm{T} 1$ at $37^{\circ} \mathrm{C}$ for $1 \mathrm{~h}$, phenol extracted and ethanol precipitated. Sample were subjected to electrophoresis on 1.5- mm-thick $5 \%$ urea-acrylamide gels, the gels dried at $80^{\circ} \mathrm{C}$ for $45 \mathrm{~min}$ and exposed for $16 \mathrm{~h}$ at $-85^{\circ} \mathrm{C}$ with Kodak XAR films with intensifying screens.

Immunohistochemistry and antibody preparation. The monkey GRP prohormone exists in two forms which both identically encode GRP, as we have previously described for human $\operatorname{GRP}(39,40)$. The sequence of the monkey GRP prohormones were derived from cDNA cloning and will be fully described elsewhere (note, monkey GRP is identical in sequence to human GRP). Two synthetic peptides corresponding to the $\mathrm{COOH}$-terminal regions of the monkey GRP prohormones were synthesized and used as immunogens for antiserum production. The synthetic peptides corresponding to monkey prohormones type 1 and 2 were MC1: Tyr-Lys-Asp-Leu-Val-Asp-Ser-Leu-Leu-Gln-Val-Leu-AsnVal-Lys-Glu-Gly-Thr-Pro-Gln-Leu-Asn-Gln-Gln and MC2: Tyr-AsnPro-Pro-Ala-Glu-Pro-Ala-Met-Thr-Met-Met-Ala-Ser-Leu-Lys-GlyGlu-Lys-Gln-Asn-Pro. The peptides were conjugated to Keyhole Limpet Hemocyanin using $N$-ethyl- $N^{\prime}$ (3-dimethylaminopropyl) carbodiimide (Calbiochem-Behring, La Jolla, CA). New Zealand White rabbits were immunized subcutaneously with $100 \mu \mathrm{g}$ peptides using complete Freund's adjuvant in the initial injections and incomplete Freund's adjuvant in the subsequent injections.

Immunohistochemistry was performed using monoclonal antibody (2A11) against amphibian bombesin that cross reacts equally with GRP (18) and with the antisera against the two synthetic monkey GRP prohormone $\mathrm{COOH}$-terminal peptides (MC1 and MC2). Bound antibody was visualized with the avidin-biotin complex $(\mathrm{ABC})$ (Vector Laboratories, Inc., Burlingame, CA) immunoperoxidase technique using diaminobenzadine as the substrate as described by Watts and Swanson (41). Controls consisted of nonimmune rabbit serum, or anti-bombesin antiserum (2A11) preadsorbed with bombesin $(10 \mu \mathrm{g} / \mathrm{ml})$, or GRP prohormone antisera adsorbed with $\mathrm{MC} 1$ or $\mathrm{MC} 2$. No positive reactions were detected in any of the controls. Combined in situ hybridization-immunohistochemistry was performed as described by Watts and Swanson (41) as modified by Lorang et al. (42). After immunohistochemicallyprocessed sections were developed with diaminobenzadine, they were rinsed four times in $.02 \mathrm{M}$ potassium-phosphate-buffered saline (KPBS), $\mathrm{pH}$ 7.4, dried overnight in a vacuum desiccator then subjected to in situ hybridization as described below.

Serial sections of some monkey fetal lung $(60,80$, and 125 day gestation) were also stained for chromogranin $\mathrm{A}$ and neuron specific enolase by the $\mathrm{ABC}$ immunoperoxidase technique.

In situ hybridization. In situ hybridization was performed as described by Angerer et al. (43) and Lorang et al. (42). In brief, tissues were fixed in $4 \%$ paraformaldehyde for $6-8 \mathrm{~h}$, and transferred to $15 \%$ sucrose in $0.1 \mathrm{M}$ PBS for $16 \mathrm{~h}$ at $4^{\circ} \mathrm{C}$. The tissues were then embedded in Tissue-TEK O.C.T. compound (Miles, Elkhart, IN) and frozen in powdered dry ice, and stored at $-80^{\circ} \mathrm{C}$. Tissue sections were cut on a cryostat at 5-10 $\mu \mathrm{m}$, placed onto poly-L-lysine and gelatine coated slides, and dried overnight under vacuum. Slides were refixed with $4 \%$ paraformaldehyde for $15 \mathrm{~min}$, washed $2 \times$ with $0.1 \mathrm{M}$ PBS, treated with $2 \mu \mathrm{g} / \mathrm{ml}$ proteinase $\mathrm{K}, 0.1 \mathrm{M}$ triethanolamine, and $2.5 \mu \mathrm{l} / \mathrm{ml}$ acetic anhydride. Hybridization was carried out with monkey GRP receptor cRNA probe prepared as described above. ${ }^{35}$ S-labeled probe $\left(10 \times 10^{6}\right.$ cpm) was applied to each slide in a volume of $70 \mu \mathrm{l}$ of hybridization buffer ( $60 \%$ formamide, $12 \%$ dextran sulfate, $0.25 \mathrm{M} \mathrm{NaCl}, 2 \times$ Denhardt' solution, $1 \mathrm{mM}$ EDTA, $20 \mathrm{mM}$ DTT, $0.5 \mathrm{mg} / \mathrm{ml}$ tRNA, and 10 $\mathrm{mM}$ Tris, $\mathrm{pH} 8.0$ ). Coverslips were applied and slides were incubated in a moist closed chamber at $55^{\circ} \mathrm{C}$ for $20-24 \mathrm{~h}$. Slides were washed in $4 \times$ SSC for $5 \mathrm{~min} \times 4$, treated with $20 \mu \mathrm{g} / \mathrm{ml}$ ribonuclease A to digest any remaining unhybridized probes, and then washed sequentially at room temperature in $2 \times, 1 \times$ and $0.5 \times$ SSC $10 \mathrm{~min}$ for each wash, and in $0.1 \times \mathrm{SSC}$ at $65^{\circ} \mathrm{C}$ for $30 \mathrm{~min}$. Sections were then dehydrated in ethanol, air-dried, and dipped in Kodak NTB-2 autoradiographic emulsion. Slides were exposed for 7-14 d, developed and slides not previously processed for immunohistochemistry were counterstained with hematoxylin.

Fetal monkey lung organ cultures. A modification of the Trowell 

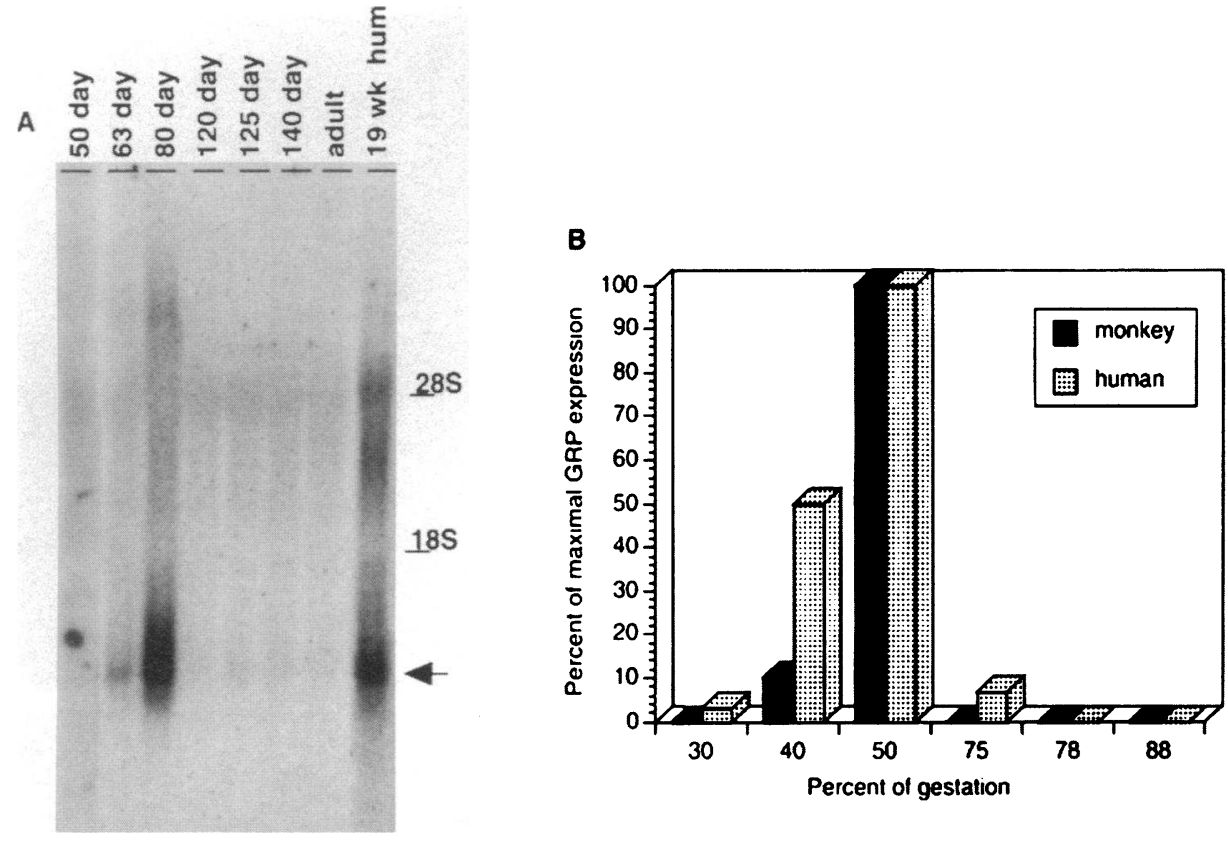

Figure 1. Analysis of GRP mRNA expression in fetal and adult monkey lung. (A) Northern blot analysis of GRP mRNAs. $10 \mu \mathrm{g}$ of total RNA from tissues shown were subjected to electrophoresis and hybridized to a monkey GRP cRNA probe as described in Methods. (Lanes 1-6) Fetal monkey lung from the gestational ages shown; (lane 7) adult monkey lung; (lane 8) 19-wk human fetal lung. The mobilities of the 28 and $18 \mathrm{~S}$ ribosomal RNAs are as shown. The arrow shows the position of the hybridizing GRP mRNA. (B) Comparison of the time course of GRP mRNA expression in monkey and human fetal lung. Data for GRP mRNA expression in human fetal lung is from Spindel et al. (17).

organ culture method was used as described by Jaskoll et al. (44). Fetal lungs from 60-, 70-, and 80-d-gestational rhesus monkeys were excised on ice and cut into $1 \mathrm{~mm}^{3}$ pieces using aseptic technique. Sections were taken only from peripheral parts of lung to avoid large central airways and blood vessels. This also served to minimize chances of biasing results by having unequal distribution of centrally and peripherally derived sections in experimental groups. The lung explants were placed on Transwell microporous membrane inserts in 6 well culture clusters (Costar, Cambridge, MA) and cultured in a serum free, chemically defined medium (Fitton-Jackson modification $B^{B G J}{ }_{b}$, GIBCO BRL, Grand Island, NY) containing $100 \mathrm{U} / \mu \mathrm{g}$ penicillin/streptomycin in $5 \%$ $\mathrm{CO}_{2} /$ air at $37^{\circ} \mathrm{C}$. To study the effects of bombesin and its antagonists on the growth of monkey fetal lung in vitro, lungs were incubated in the presence or absence of bombesin ( 1 and $10 \mathrm{nM})$; the GRP receptor antagonists, D-Phe ${ }^{6}$ bombesin (6-13) propylamide (BIM-26147) (45) or D-fluorylamide-Phe ${ }^{6}$-bombesin (6-13)-methylester (BIM-26226) (46). Peptides were present though the entire culture period and media + peptides were changed daily to limit peptide degradation. After $5 \mathrm{~d}$ in culture, fetal lung explants were fixed in Zamboni's fixative or $4 \%$ paraformaldehyde in borate buffer, $\mathrm{pH} 9.5$, and then sectioned and subjected to hematoxylin/eosin staining and or immunohistochemical staining and in situ hybridization. Image analysis was performed on sections as described below.

5-Bromo-2'-deoxy-uridine ( $\mathrm{Brd} \dot{U})$ labeling. BrdU-labeling was used to measure the effects of bombesin and its antagonist on DNA synthesis and cell proliferation. BrdU-labeling was performed using reagents and protocols supplied by Amersham (Cell Proliferation Kit, Amersham Corp., Arlington Heights, IL). Fetal lung from a 60-d-gestation rhesus monkey was cultured in $\mathrm{BGJ}_{\mathrm{b}}$ medium either with or without added bombesin $(10 \mathrm{nM})$ in $5 \% \mathrm{CO}_{2} /$ air at $37^{\circ} \mathrm{C}$ for $48 \mathrm{~h}$, then pulselabeled with BrdU ( final dilution = 1:1,000) for 60 min. After labeling, tissues were washed in PBS for 15 min, fixed in Zamboni's fixative, and processed for frozen sectioning. BrdU labeling was visualized by immunohistochemistry using a specific BrdU monoclonal antibody and sections counterstained with $0.25 \%$ thionin.

Morphologic and statistical analysis. The Optimas Bioscan image analysis program (v. 4.0) was used to quantify airway size and number and to count BrdU-labeled cells in cultured lung. For each treatment, at least ten fields (field area $=2 \mathrm{~mm}^{2}$ ) were analyzed. Within each treatment, fields counted were chosen at random from multiple sections, to minimize bias of choosing adjacent sections with similar sized airways. Within each field, all airways were counted and the internal diameter of each airway recorded in a spreadsheet (Excel 4.0, Microsoft Inc, Redding, WA) to allow construction of histograms of airway size and number. Comparisons of airway size and number were made by 1-, 2-, or 3-way ANOVA using either StatView 2.01 or SuperAnova 1.11 (Abacus Concepts, Berkeley, CA) on a Macintosh IIFX. Post hoc tests were performed with Fisher's LSD.

The number of unlabeled and BrdU-labeled cells in developing airways were counted in 10 fields per group. Within each field, in every airway that contained labeled cells, the number of labeled and unlabeled cells was determined. This allowed calculation of the percentage of labeled epithelial cells per field and the average number of BrdU labeled cells per airway.

\section{Results}

GRP and GRP-R gene expression was analyzed by three different methods. Northern blot analyses were performed to determine GRP mRNA expression in fetal and adult monkey lung; RNase protection assays were performed to demonstrate GRP$\mathrm{R}$ expression in lung tissue and in situ hybridization analyses were performed to determine cell type and relative number of cells containing GRP and GRP-R mRNAs.

By Northern blot analysis, GRP mRNA was not detectable in 50-d fetal lung; first detectable at 63 d gestation, reached highest levels at 80 days gestation and then declined to near adult levels by $120 \mathrm{~d}$ gestation (Fig. $1 \mathrm{~A}$ ). Adjusting for length of gestation ( $160 \mathrm{~d}$ for monkey, $40 \mathrm{wk}$ for human), this time course is quite similar to the pattern of GRP expression we previously reported in human fetal lung (Fig. $1 B$ ) (17). In both monkeys and humans, lung GRP mRNA expression begins at $30 \%$ of gestation, reaches peak levels by $50 \%$ gestation, and then rapidly declines to adult levels by $75 \%$ of gestation (Fig. $1 \mathrm{~B}$ ).

In situ hybridization localized GRP mRNA to PNEC and neuroepithelial bodies in both bronchi and bronchioles in fetal and neonatal monkey lung (Fig. $2 \mathrm{~A}$ ). That these cells contained 

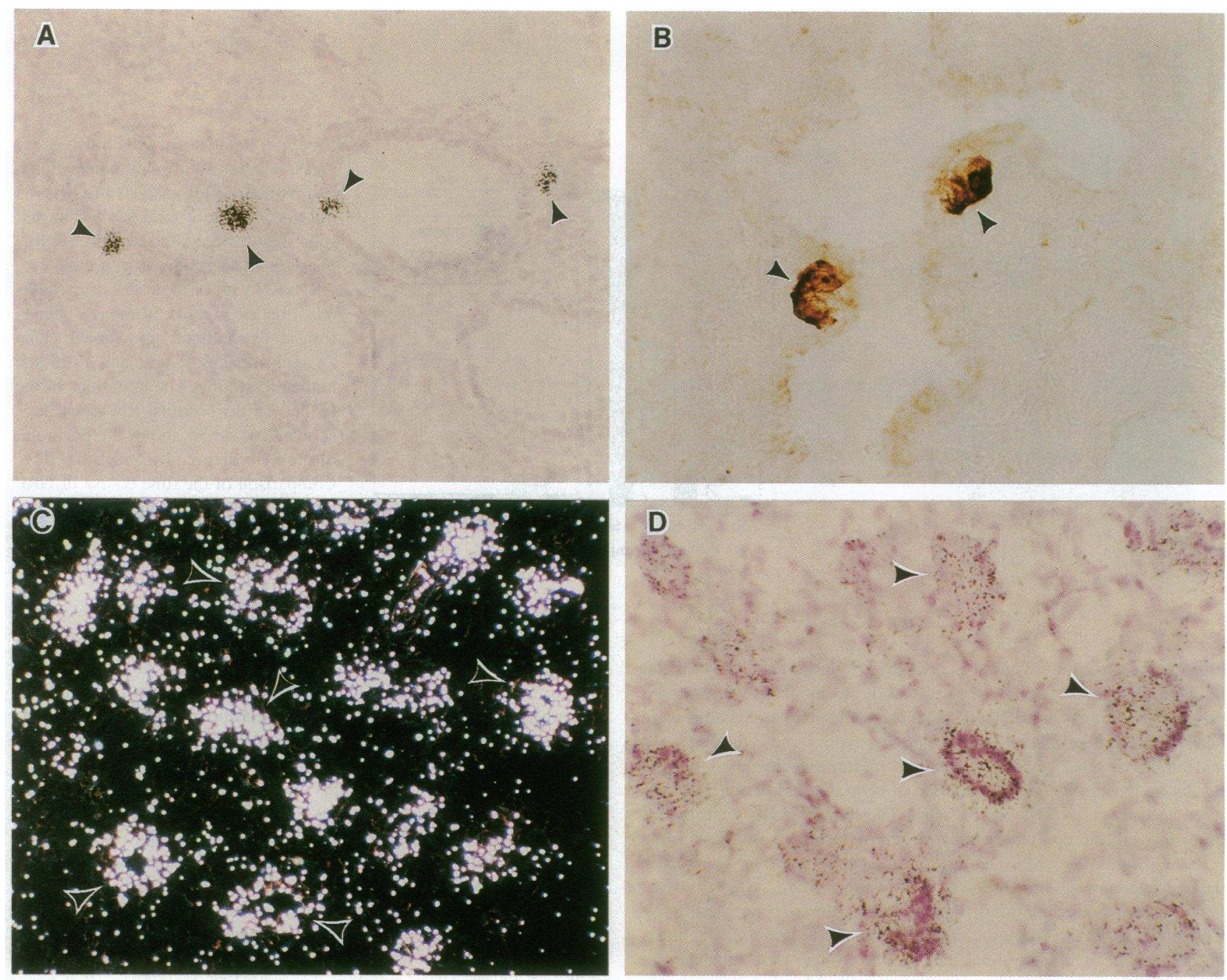

Figure 2. In situ hybridization and immunohistochemistry of GRP expression in fetal monkey lung. $(A)$ In situ hybridization of 125-d gestation monkey lung with ${ }^{35}$ S-labeled antisense GRP cRNA demonstrates hybridizing foci (arrowheads) corresponding to GRP-positive neuroendocrine cells $(\times 180)$. (B) Immunohistochemical staining of 125-d gestation monkey lung with bombesin antibody 2A11 (18) demonstrates GRP-positive neuroendocrine cells (arrowheads) at the bifurcations of a bronchiole $(\times 225)$. ( $C$ and $D)$ Dark field $(C)$ and light field $(D)$ photographs of in situ hybridization of 80-d gestation monkey lung with ${ }^{35}$ S-labeled antisense GRP cRNA showing the presence of GRP mRNA in cells of budding airways (arrowheads) $(C$ and $D \times 290)$.

GRP was demonstrated by strong staining with bombesin monoclonal antibody $2 \mathrm{~A} 11$ (18) (Fig. $2 B$ ) and by staining with antibodies to the monkey GRP prohormones (not shown). GRP-positive neuroendocrine cells were localized both proximally and distally, predominantly in bronchioles, frequently at points of bifurcation (Fig. $2 B$ ). Absorption of the antibombesin antiserum with bombesin and the prohormone antiserum with peptides $\mathrm{MC1}$ and MC2 blocked staining in serial sections. Cells were identified as PNEC by morphology, location and by positive staining with a human anti-chromogranin antibody $(17,47,48)$. Thus similar cell types express GRP in monkey and human fetal lung.

Between 63 and 80 d gestation GRP mRNA was present not only in the neuroendocrine cells, but also in cells of budding airways (Fig. 2, $C$ and $D$ ). These cells however did not show any staining with bombesin antibody $2 \mathrm{~A} 11$ nor with the antibod- ies against the monkey GRP prohormones. Thus, GRP mRNA is transiently expressed in airway progenitor cells but may not be translated.

The presence of GRP-R mRNA was determined by RNase protection analysis of total RNA from monkey fetal and adult lungs using a probe to exon 3 of the monkey GRP receptor (Fig. 3). GRP-R expression was detectable in monkey lung by $63 \mathrm{~d}$ gestation, plateaued from 80 to $140 \mathrm{~d}$ gestation and markedly decreased in adult lung (Fig. 3 ). Thus this time course parallels the time course observed for GRP mRNA expression. Using the same GRP receptor exon 3 probe and bombesin antibody $2 \mathrm{~A} 11$, combined GRP-R in situ hybridization/GRP immunohistochemistry was performed to determine which cells expressed the GRP-R mRNA (Fig. 4). As shown in Fig. 4, GRP$\mathrm{R}$ was expressed primarily by cells lining developing airways. As evident in Fig. $4 C$, hybridization is located luminally and 

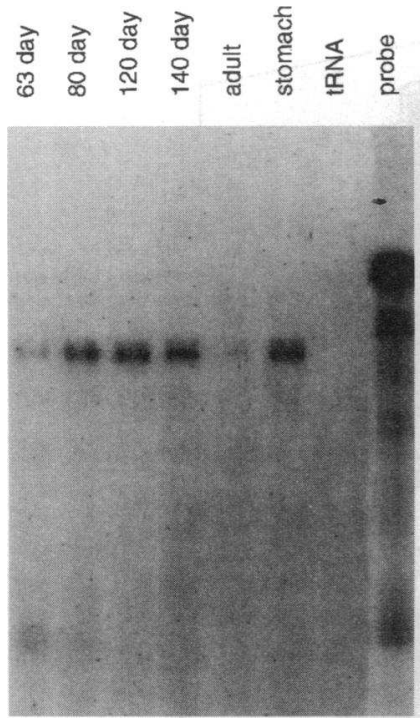

Figure 3. RNase protection analysis of GRP-R mRNA expression in fetal and adult monkey lung. Adult monkey stomach (lane $6,10 \mu \mathrm{g}$ ) served as a positive control (61). Overexposure of undigested probe shows $>98 \%$ purity. $10 \mu \mathrm{g}$ of total RNA prepared from monkey fetal and adult lungs were subjected to solution hybridization with the monkey GRP receptor CRNA probe as described in Methods. Size of input probe (including flanking vector) sequences $=320$ bases; size of protected fragment $=250$ bases. Protected fragments were of appropriate sizes as determined by DNA sequencing ladders (not shown). in areas of cellular thickening. The expression of GRP-R in airways appears bimodal in that either many cells in an airway section express the GRP-R or no cells in an airway section express the GRP-R. The proximity of the GRP-R expressing epithelial cells to the GRP expressing PNEC suggests that GRP released from PNEC may act on the airway epithelial cells. As shown in Fig. 4, $D$ and $E$ silver grains also overlayed some PNEC suggesting that some GRP-expressing cells may also express the GRP-R.

To determine the effects of GRP on airway development, organ culture was performed on 60-, 70-, and 80-d fetal monkey lung, periods of maximal GRP and GRP-R expression. Tissues incubated for $5 \mathrm{~d}$ maintained morphology characteristic of healthy lung tissue as shown in Fig. 5. The representative section shown in Fig. 5 shows the stimulation of airway size and number caused by $10 \mathrm{nM}$ bombesin. The effects of bombesin and antagonists were quantified by image analysis and results are presented in Figs. 6-8. Figure 6 shows a histogram of the number of airways of the given sizes (in $10 \mu \mathrm{m}$ increments) for each treatment. Bombesin at both 1 and $10 \mathrm{nM}$ significantly increased airway number and size at 60,70 , and $80 \mathrm{~d}$ gestation. The effect of bombesin was completely blocked by the specific
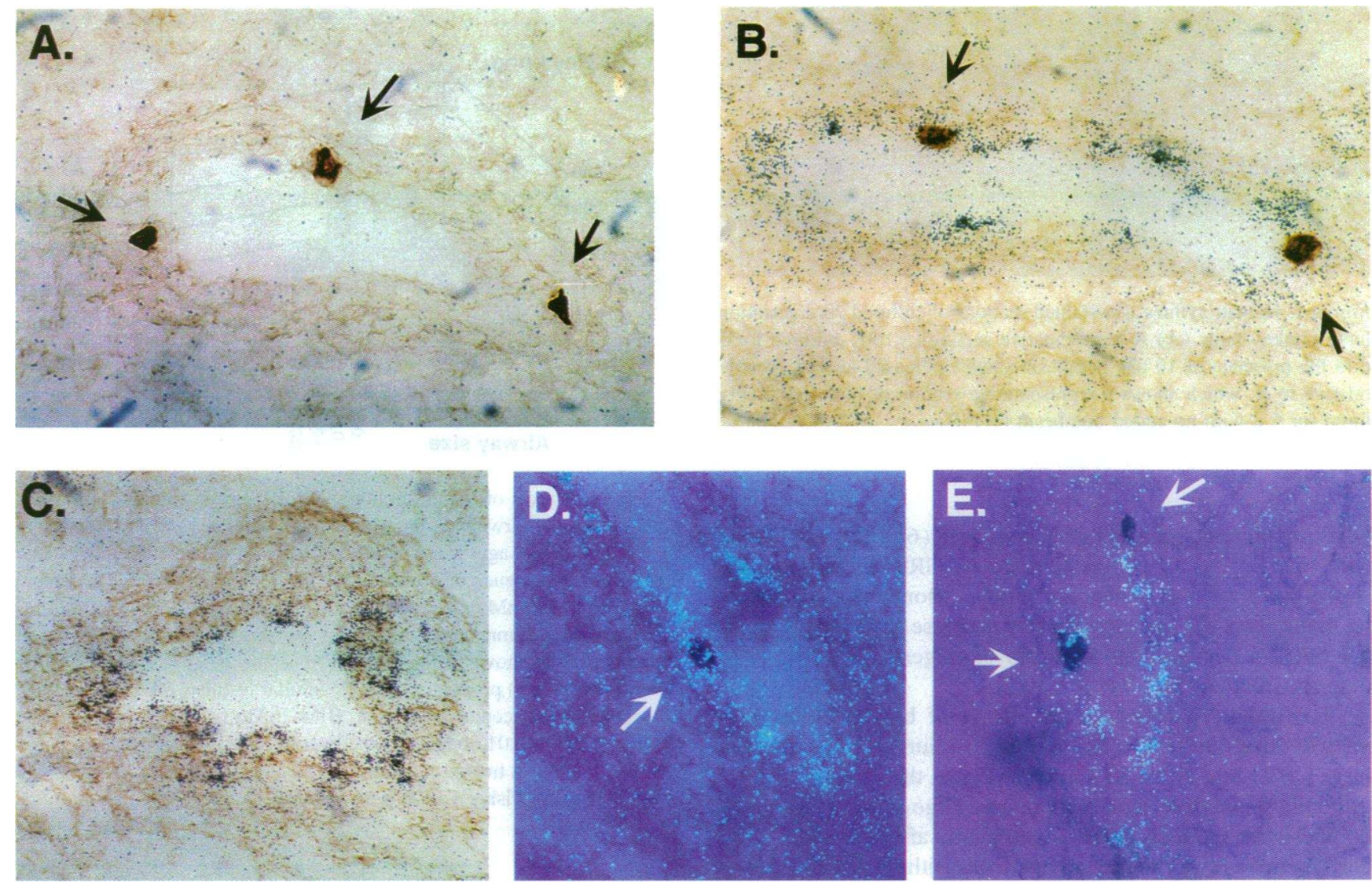

Figure 4. Double in situ hybridization-immunohistochemical analysis of GRP-R and GRP expression in fetal monkey lung. All sections were exposed to bombesin antibody $2 \mathrm{~A} 11$ and probed with the antisense or sense ${ }^{35}$ S-labeled GRP-R cRNA probe. All fields are from $80-\mathrm{d}$ fetal monkey lung at $\times 150$. Arrows point to GRP-immunostaining cells. $(A)$ Brightfield of hybridization to GRP-R sense probe showing no specific hybridization around airway. ( $B$ and $C$ ) Brightfield of hybridization to GRP-R antisense probe. Note how hybridization tends to be luminal and in areas of cellular thickening. ( $D$ and $E$ ) Darkfield with polarized-epiluminescent illumination showing how GRP-R hybridization overlies some, but not all, GRPpositive neuroendocrine cells. 

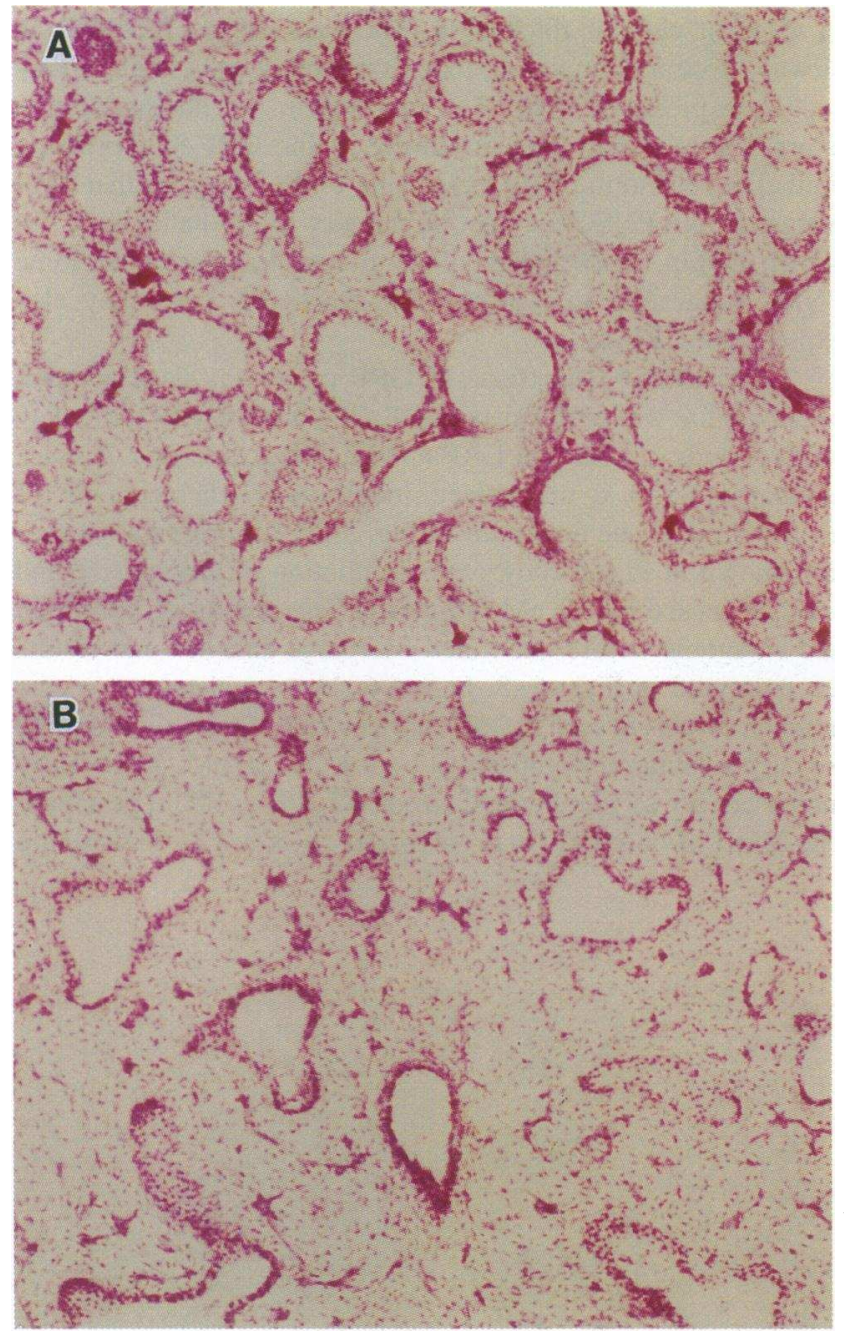

Figure 5. Hematoxylin/eosin-stained sections of cultured 70-d gestation fetal monkey lung. $(A)$ A representative section $(\times 160)$ cultured for 5 $\mathrm{d}$ in the presence of $10 \mathrm{nM}$ bombesin shows increased airway growth relative to $B$. which shows a representative section of lung tissue cultured for $5 \mathrm{~d}$ with no added bombesin $(\times 140)$.

GRP receptor antagonist D-Phe ${ }^{6}$ bombesin $(6-13)$ propylamide $(45,46)$ (Fig. 6) as well as by a second GRP receptor antagonist, BIM-26226 (46) (data not shown). Bombesin antagonists by themselves did not significantly decrease total airway number but did decrease the numbers of larger-sized airways as described below (Fig. 7).

To further characterize the effects of bombesin, airways were divided into small (10-40 nm), medium (41-70 nm) and large ( $>71 \mathrm{~nm}$ ) sizes. As shown in Fig. 7, the strongest effects of bombesin were seen on medium and large airways. Although bombesin antagonists did not significantly affect the total number of airways per field, comparison within size categories showed significant decreases in larger-sized airways with antagonist treatment (Fig. 7).

Overall, the stimulatory effects of bombesin on fetal monkey lung development resulted in an apparent increase in the growth rate of airways. This can be appreciated by comparing $80-\mathrm{d}$ fetal monkey lung cultured in the absence of bombesin to 60-
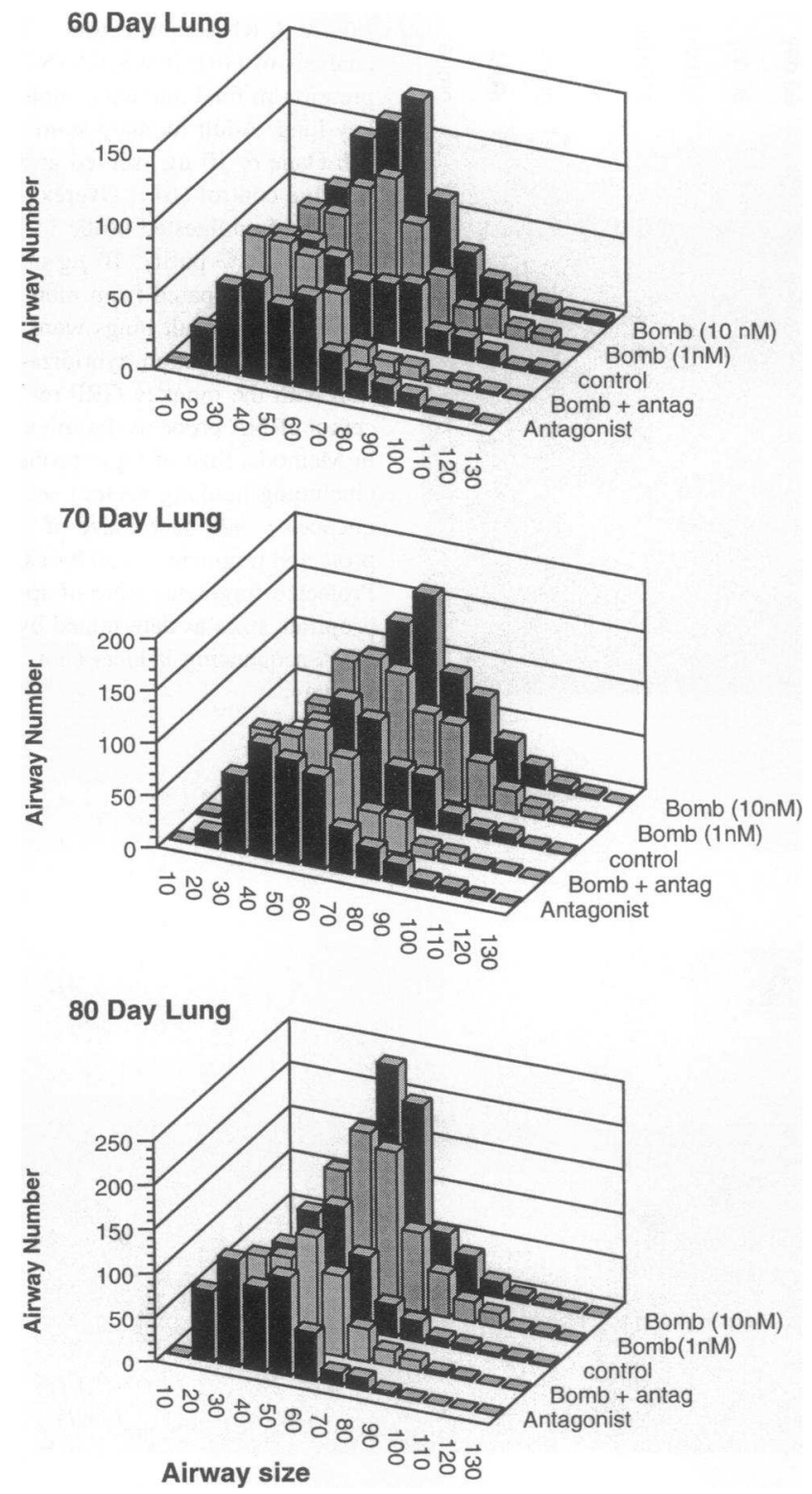

Figure 6. Effects of bombesin and GRP receptor antagonists on size and number of airways in fetal lung organ culture. Fetal monkey lungs of the gestational ages shown were cultured without any treatment (control), in the presence of bombesin ( $1 \mathrm{nM}$ and $10 \mathrm{nM})$, GRP receptor antagonist $(100 \mathrm{nM})$ and bombesin + antagonist $(10 \mathrm{nM}+100 \mathrm{nM})$. Airways in $102-\mathrm{mm}^{2}$ fields per group were counted as described in the Methods. Data shown is for the GRP receptor antagonist D-Phe ${ }^{6}$

bombesin (6-13) propylamide (45). Similar results were obtained with a second GRP receptor antagonist, BIM-26226 (46) (results not shown). ${ }^{*} P<0.01$ comparing the overall number of airways in 1 and $10 \mathrm{nM}$ bombesin treated lungs to control lung cultures by 3-way ANOVA using Fisher's LSD post hoc test.

$\mathrm{d}$ fetal lung cultured in the presence of $10 \mathrm{nM}$ bombesin (Fig. 8 ). Bombesin increased the number of airways in each size category, such that there were no longer significant differences between the treated 60-d lung and the untreated 80-d lung (Fig. 8).

To determine if bombesin treatment stimulated DNA repli- 

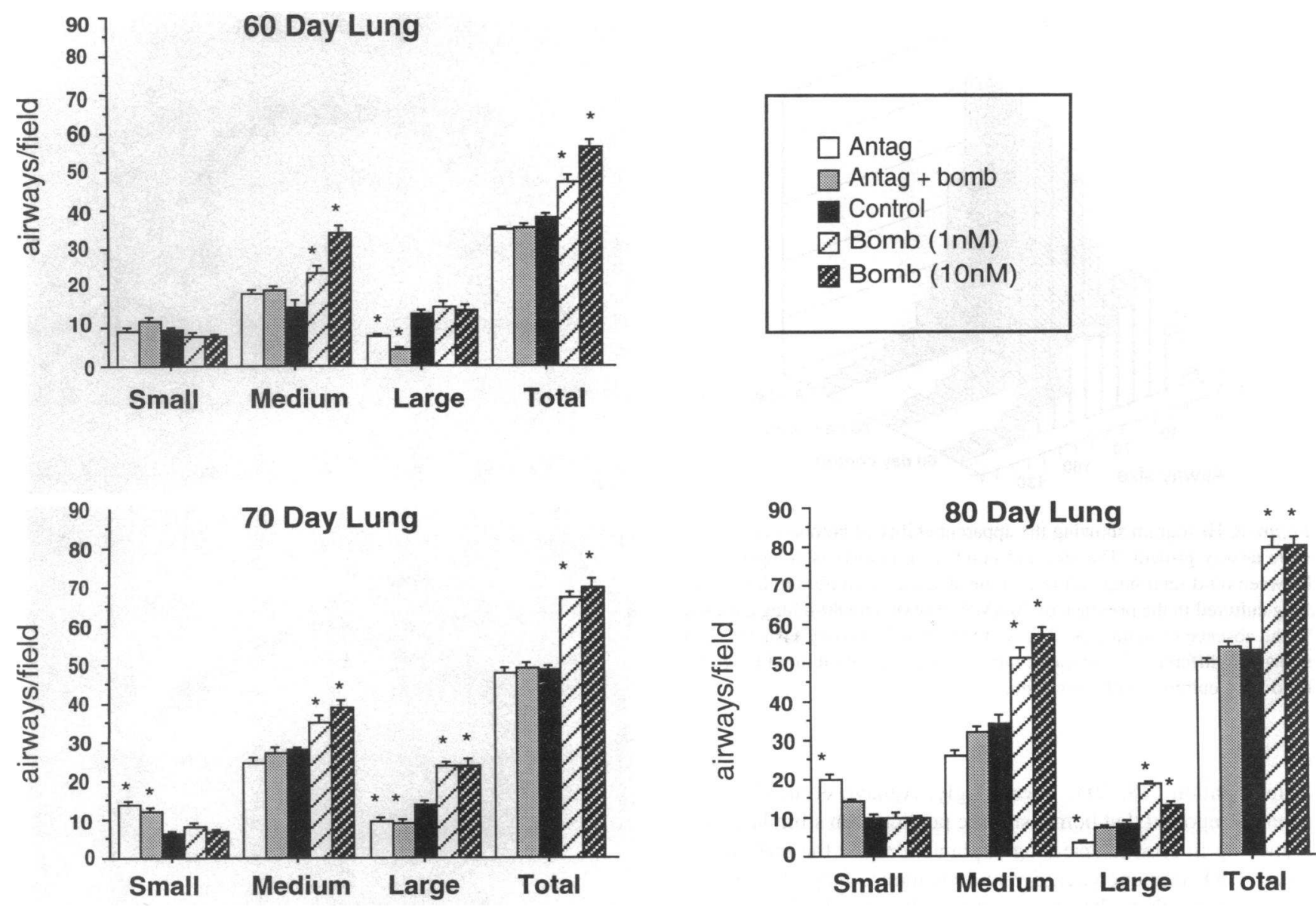

Figure 7. Histogram showing the effects of bombesin and its antagonists on the total airway number and number of small, medium and large sized airways (small $=10-40 \mu \mathrm{m}$, medium $=41-70 \mu \mathrm{m}$, large $=70-150 \mu \mathrm{m}$ ) in fetal monkey lungs. Bombesin at 1 and $10 \mathrm{nM}$ significantly increased total airways in 60, 70, and 80-d lungs. Bombesin significantly increased the number of medium and large airways, but not the number of small airways. Antagonist treatment did not significantly affect overall number of airways, but did significantly decrease the number of large airways and increase the number of small airways at most time points. ${ }^{*} P<0.05$ compared to number of control airways of the same age and size by 1 way ANOVA followed by Fisher's LSD post hoc tests.

cation and to determine the target cells, BrdU labeling was performed. As shown in Fig. 9, the majority of cells that took up BrdU lined developing airways. Treatment with $10 \mathrm{nM}$ bombesin significantly increased both the number and percentage of BrdU-labeled airway epithelial cells as compared to untreated lung (Fig. 9). The majority of cells labeled by BrdU were located in the epithelium of developing airways and relatively fewer mesenchymal cells were labeled (Fig. $9 A$ ).

\section{Discussion}

Northern blot analyses demonstrated that GRP mRNAs are elevated in fetal rhesus monkey lung from 63 to $80 \mathrm{~d}$ gestation. This transient increase of GRP mRNA in midgestational fetal monkey lung is similar to the increased GRP mRNA expression observed from 16 to 30 wk gestation in human fetal lung (17). Also like human lung, in situ hybridization localized the GRP mRNA in fetal monkey lung to neuroendocrine cells. GRP immunostaining appeared at about the same time when GRP mRNA expression was first demonstrated, and was consistently present in the neuroendocrine cells in both fetal and neonatal lungs. This strong similarity between monkey and human in the pattern and time course of GRP gene expression makes the monkey a potentially valuable model to characterize the role of GRP in fetal lung development.

In human lung, as in rhesus monkey the period of gestation during which the GRP gene is activated corresponds to the latter part of the pseudoglandular stage and to the canalicular phase of pulmonary development $(17,49,50)$. This phase is characterized by considerable extension and branching of the respiratory bronchioles which are lined by cuboidal epithelium and situated close to the capillary system. At places where direct contact between bronchioles and capillaries occurs, the epithelial cells may be flattened to squamous epithelium $(49,50)$. Developing monkey lung generally follows a similar time course as does human lung, and alveolarization does not significantly start until day 95 of gestation (51). Thus in the primate, GRP is expressed in the pseudoglandular and canalicular phase during initial airway formation. By contrast, in rodents, GRP is expressed at the end of gestation $(28,29)$. This would suggest that in primates, GRP may influence airway branching, but in rodents, GRP has more of an effect in terminal airway 


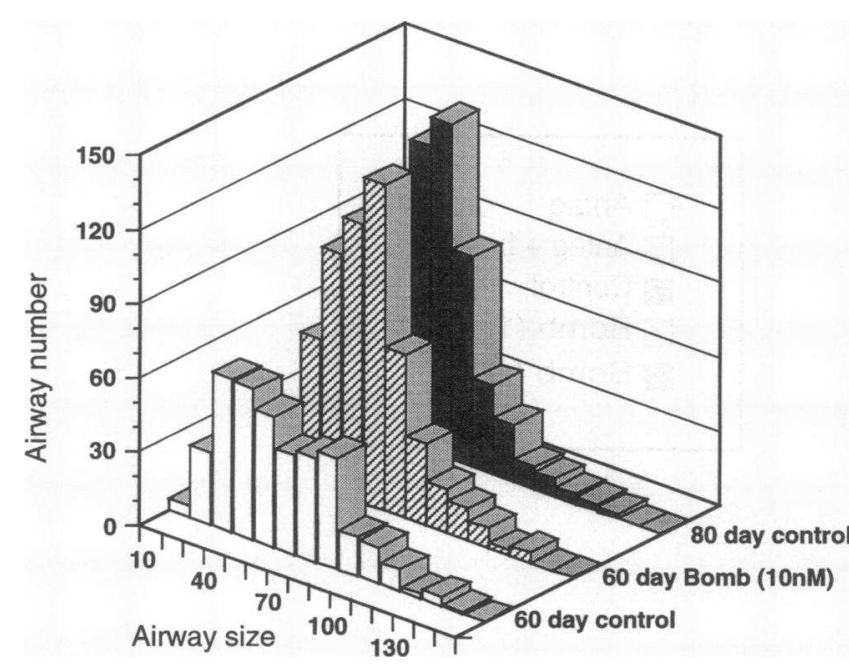

Figure 8. Histogram showing the apparent ability of bombesin to accelerate airway growth. The size and number of airways is compared between 60-d fetal lung cultured in the absence of bombesin, 60-d fetal lung cultured in the presence of $10 \mathrm{nM}$ bombesin and 80-d lung cultured in the absence of bombesin. 2-way-ANOVA followed by Fisher's LSD shows no difference in airway number between 80-d cultured lung and 60-d lung cultured with bombesin.

differentiation $(28,29)$. Interestingly, Aguayo et al. (30) has recently reported that bombesin-like peptides can stimulate lung branching in fetal mouse lung explants, despite the inability to detect GRP immunoreactivity in fetal mouse lung. This raises the possibility that other, as yet undescribed bombesin-like peptides may be active in rodent lung.

A surprising finding in this study was that at midgestation, GRP mRNA was present not only in the neuroendocrine cells, but also in the epithelial cells of budding airways. This finding is similar to the recent report of calcitonin gene-related peptide in serous cells of rat trachea (52). In contrast to GRP expression in neuroendocrine cells in which strong immunostaining could be demonstrated, no GRP or GRP prohormone immunostaining could be detected in the budding airways. This suggests that GRP mRNA is present, but not translated in airway progenitor cells. This would be similar to the many human lung neoplasms which also express but do not translate the GRP mRNA and thus may help explain why so many different lung neoplasms express the GRP mRNA $(53,54)$. It is also possible that GRP is present at low concentrations or is rapidly secreted, but not stored in these cells, thus making immunohistochemical detection difficult. Another possibility which cannot be ruled out is the presence of a related, but different GRP-mRNA whose translation product is not detected by the antibodies used. Preliminary screening of a cDNA library from 80-d fetal lung however did not reveal any clones encoding new bombesin-like peptides. The expression of some but not all neuroendocrine markers (i.e., no chromogranin expression) raises the still poorly understood question of the relation of airway progenitor cells to neuroendocrine cells or to the progenitors of neuroendocrine cells.

Bombesin-like peptides have been implicated as autocrine growth factors influencing pathogenesis and progression of some $\operatorname{SCLC}(18,19,27)$ and the expression of GRP receptor
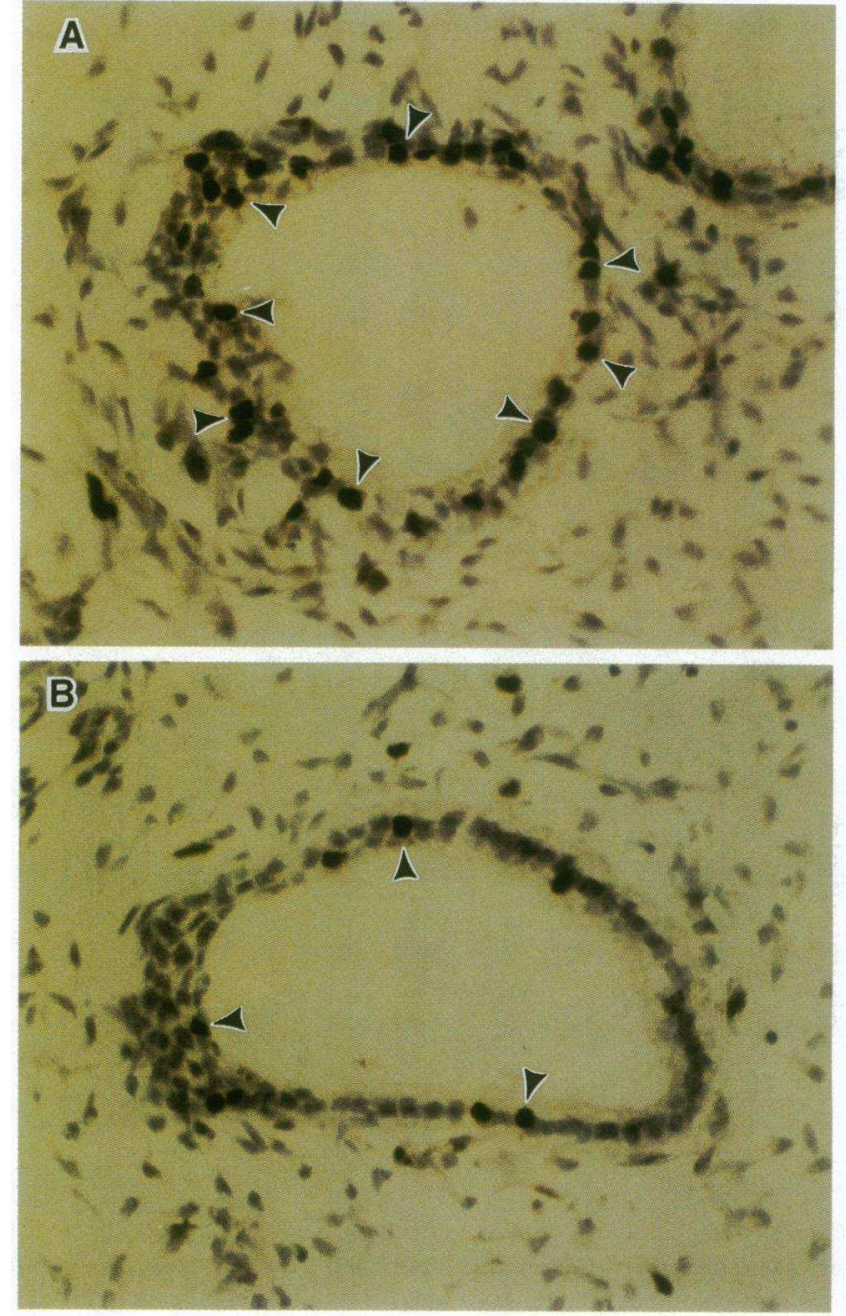

C

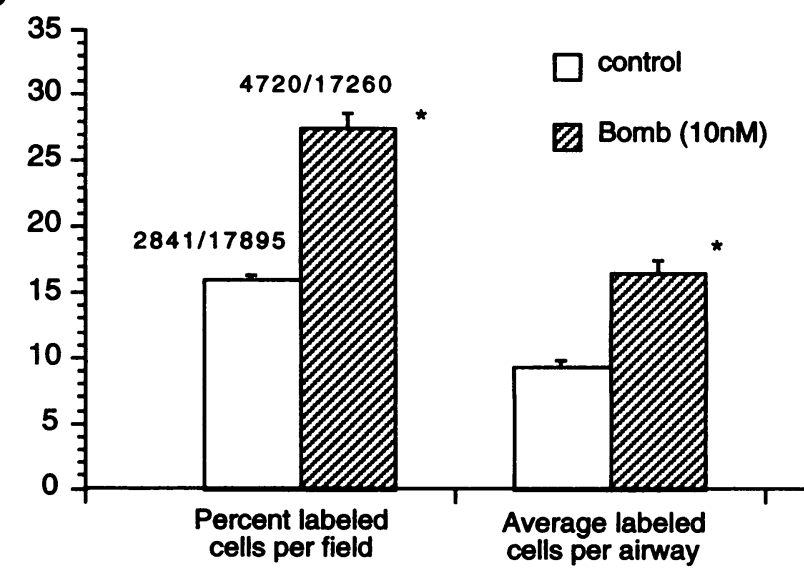

Figure 9. Effect of bombesin on incorporation of BrdU into cultured fetal monkey lung. 60-d fetal monkey lung was cultured in the $(A)$ presence of bombesin ( $10 \mathrm{nM}$ ) or $(B)$ absence of bombesin and pulse-labeled with BrdU. Sections $(\times 550)$ were processed and stained for BrdU as described in Methods. As examples, arrowheads point out some of the BrdU-positive cells. $(C)$ Percentage of BrdU-positive cells per 2- $\mathrm{mm}^{2}$ field and average number of BrdU cells per airway in bombesin-treated and untreated lung. Airways in $102-\mathrm{mm}^{2}$ fields were counted per group; the total number of BrdU-positive cells/total cells counted are shown over the bars. ${ }^{*} P<.01$ compared to control by Students' $t$ test. 
in SCLC is well documented $(23,34,55-57)$. The expression of GRP ligand in fetal and neonatal lung of human and other mammals is also well described $(8,10,13,14,17)$, but the expression of GRP receptors in normal fetal primate lung has not been described. In this study, we have demonstrated GRP$R$ gene expression in normal monkey fetal lung by RNase protection and in situ hybridization analyses. In situ hybridization shows marked staining around the developing airways (Fig. 4) which suggests that developing airway epithelial cells may be the cells that respond to the mitogenic effects of GRP during lung development. Consistent with this, both GRP ligand and receptor are expressed in monkey fetal lung at about the same stages. Thus one likely hypothesis is that GRP synthesized by PNEC is a paracrine growth factor for epithelial cells of developing airways which express GRP-R.

The observation of GRP-R in airway epithelial cells is consistent with the observations by Willey et al. (6) and Siegfried et al. (20) that bombesin and GRP are mitogenic for human bronchial epithelial cells. The double in situ hybridization/immunohistochemical analyses suggest that some PNEC express both GRP and GRP-R. This is consistent with the findings by Speirs et al. (58) that GRP stimulates the growth of rabbit PNEC. This is also consistent with the expression of GRP-R by some SCLC and the existence of an autocrine feedback loop as first proposed by Cuttitta et al. (18) in which SCLC both secrete and respond to GRP. While our data shows GRP-R hybridization overlying PNEC and strongly suggests that PNEC express GRP-R, without confocal microscopy we cannot definitively rule out that the hybridization observed derives from overlying cells. In examining the expression of GRP-R in developing airways, it is striking that not all airways express GRP$R$, rather only a subset of airways express GRP-R, and typically, in an "activated"' airway many cells will express GRP-R. This suggests that there may be a local, paracrine factor that turns on GRP-R expression in developing airways. The identification of this factor is likely to have significance both for normal as well as neoplastic lung growth.

To determine if the peak expression of GRP mRNA in developing of lung coincided with effects of bombesin-like peptides on lung development, organ culture was performed. As shown in Fig. 6, bombesin increased in a dose-dependent manner both airway size and number. While our methodologies did not allow a specific quantitation of branching morphogenesis, the increase in number suggests a concomitant increase in branching. Interestingly we did not observe an increase in small airways which might be expected with increases in branching. This may relate to the relative rapidity of stimulation of airway growth by bombesin or alternately that rather than stimulating airway branching, bombesin simply stimulates increases in airway linear growth and diameter. That this increase was achieved by stimulation of cell division was confirmed by labeling with BrdU, in which bombesin increased DNA synthesis primarily in the epithelial cells of budding airways and had relatively weaker effects on mesenchymal cells.

Considering that an important aspect of both the pseudoglandular and the canalicular phase is extension and branching of airways $(49,50)$, the stimulatory effects of bombesin we observed in organ culture suggests that the peak expression of GRP in neuroendocrine cells in fetal lung is related to the rapid airway development that is ongoing at that time. It is, however, necessary to keep in mind that besides bombesin, other growth factors, such as epidermal growth factor (EGF) and transforming growth factor- $\beta 1$ (TGF- $\beta 1$ ), may play a synergistic role in fetal lung development $(59,60)$. Both EGF and EGF receptor have been demonstrated in primitive airways. For example, addition of exogenous EGF to lungs in culture resulted in significant stimulation of branching morphogenesis and increase of DNA, RNA and protein content (59). The interaction between these factors and GRP clearly deserves further study.

Stimulatory effects of bombesin were observed in 60-, 70-, and $80-\mathrm{d}$ lung. Whether bombesin would continue to be stimulatory in lungs from older monkeys will likely correlate with expression of GRP-R in airway cells. Thus critical to the regulation of airway growth will be what regulates GRP and GRP-R expression.

That the effects of bombesin could be completely blocked by two different GRP receptor antagonists is consistent with the expression of the GRP-R as detected by RNase protection and in situ hybridization. This suggests that endogenous bombesin-like peptides act to stimulate airway development by interaction with the GRP-R. Based on the immunohistochemical staining and Northern blot analysis it is reasonable to conclude this peptide is GRP. It is possible that the effects of bombesin on airway development in rodents may be mediated by other as yet uncharacterized bombesin-like peptides as GRP cannot be detected in early gestation rodent lung. The failure of GRPreceptor antagonists by themselves to block airway development in organ culture may derive from insufficient concentrations of antagonists at the site of endogenous peptide secretion, high local concentrations of endogenous peptide, or may relate to a lack of secretion of endogenous GRP because of loss of regulatory mechanisms.

In conclusion, the present study demonstrates that GRP and the GRP-R genes are expressed in monkey fetal lung primarily during the pseudoglandular and canalicular phase of pulmonary development. The pattern and time course of expression of GRP gene in developing fetal lung in monkey is similar to that in human; suggesting this will be a valuable model to determine the effects of bombesin-like peptides on lung development. The clear stimulatory effects on airway development induced by bombesin suggests potential therapeutic uses of bombesin in very early threatened or actual premature deliveries. Future in vivo studies to administer bombesin-like peptides to fetal monkeys in utero will help determine the extent of bombesin-like peptides role in lung development.

\section{Acknowledgments}

This research was supported by National Institutes of Health grants CA39237, CA53584, by the cell culture and morphology cores of $\mathrm{Na}-$ tional Institute of Child Health and Human Development Population Research Center grant P30-HD18185 and by grants from the Council on Tobacco Research. GRP antibody 2A11 was generously supplied by Frank Cuttitta and GRP receptor antagonists were generously supplied by David Coy and by Biomeasure Incorporated.

The authors wish to thank David Warburton for advice on lung organ culture and Richard Simerly for assistance with double in situ immunohistochemical analysis.

\section{References}

1. Anastasi, A., V. Erspamer, and M. Bucci. 1971. Isolation and structure of bombesin and alytesin, two analogous active peptides from the skin of the European amphibians Bombina and Alytes. Experientia. 27:166-167. 
2. McDonald, T. J., H. Jornvall, G. Nilsson, M. Vagne, M. Ghatei, S. R. Bloom, and V. Mutt. 1979. Characterization of a gastrin releasing peptide from porcine non-antral gastric tissue. Biochem. Biophys. Res. Commun. 90:227-233.

3. Reeve, J. R., Jr., J. H. Walsh, P. Chew, B. Clark, D. Hawke, and J. E Shively. 1983. Amino acid sequences of three bombesin-like peptides from canine intestine extracts. J. Biol. Chem. 258:5582-5588.

4. Roth, K. A., C. J. Evans, E. Weber, J. D. Barchas, D. G. Bostwick, and K. G. Bensch. 1983. Gastrin-releasing peptide-related peptides in a human malignant lung carcinoid tumor. Cancer Res. 43:5411-5415.

5. McDonald, T. J., M. A. Ghatei, S. R. Bloom, T. E. Adrian, T. Mochizuki, C. Yanaihara, and N. Yanaihara. 1983. Dose-response comparisons of canine plasma gastroenteropancreatic hormone responses to bombesin and the porcine gastrin-releasing peptide. Regul. Pept. 5:125-137.

6. Willey, J. C., J. F. Lechner, and C. C. Harris. 1984. Bombesin and the Cterminal tetradecapeptide of gastrin-releasing peptide are growth factors for normal human bronchial epithelial cells. Exp. Cell Res. 153:245-248.

7. Walsh, J. H., H. C. Wong, and G. J. Dockray. 1979. Bombesin-like peptides in mammals. Fed. Proc. 38:2315-2319.

8. Wharton, J., J. M. Polak, S. R. Bloom, M. A. Ghatei, E. Solcia, M. R. Brown, and A. G. E. Pearse. 1978. Bombesin-like immunoreactivity in the lung. Nature (Lond.). 273:769-770.

9. Spindel, E. R. 1986. Mammalian bombesin-like peptides. Trends Neurosci. 9:130-133.

10. Cutz, E., W. Chan, and N. S. Track. 1981. Bombesin, calcitonin and leuenkephalin immunoreactivity in endocrine cells of the human lung. Experientia. 37:765-767.

11. Track, N. S., and E. Cutz. 1982. Bombesin-like immunoreactivity in developing human lung. Life Sci. 30:1553-1556.

12. Johnson, D. E., J. E. Lock, R. P. Elde, and T. R. Thompson. 1982 Pulmonary neuroendocrine cells in hyaline membrane disease and bronchopulmonary dysplasia. Pediatr. Res. 16:446-454.

13. Ghatei, M. A., M. N. Sheppard, S. Henzen-Logman, M. A. Blank, J. M. Polak, and S. R. Bloom. 1983. Bombesin and vasoactive intestinal polypeptide in the developing lung: marked changes in acute respiratory distress syndrome. J. Clin. Endocrinol. Metab. 57:1226-1232.

14. Stahlman, M. T., A. G. Kasselberg, D. N. Orth, and M. E. Gray. 1985. Ontogeny of neuroendocrine cells in human fetal lung: II. An immunohistochemical study. Lab. Invest. 52:52-60.

15. Moody, T. W., C. B. Pert, A. F. Gazdar, D. N. Carney, and J. D. Minna. 1981. High levels of intracellular bombesin characterize human small-cell lung carcinoma. Science (Wash. DC). 214:1246-1248.

16. Erisman, M. D., R. I. Linno, O. Hernandez, R. P. DiAngustine, and L. H. Lazarus. 1982. Human lung small cell carcinoma contains bombesin. Proc. Natl. Acad. Sci. USA. 79:2379-2383.

17. Spindel, E. R., M. E. Sunday, H. Hofler, H. J. Wolfe, J. F. Habener, and W. W. Chin. 1987. Transient elevation of mRNAs encoding gastrin-releasing peptide (GRP), a putative pulmonary growth factor, in human fetal lung. J. Clin. Invest. 80:1172-1179.

18. Cuttitta, F., D. N. Carney, J. Mulshine, T. W. Moody, J. Fedorko, A. Fischler, and J. D. Minna. 1985. Bombesin-like peptides can function as autocrine growth factors in human small cell lung cancer. Nature (Lond.). 316:823-826.

19. Weber, S., J. E. Zuckerman, D. G. Bostwick, K. G. Bensch, B. I. Sikic, and T. A. Raffin. 1985. Gastrin-releasing peptide is a selective mitogen for smal cell lung carcinoma in vitro. J. Clin. Invest. 75:306-309.

20. Siegfried, J. M., P. J. Guentert, and A. L. Gaither. 1993. Effects of bombesin and gastrin-releasing peptide on human bronchial epithelial cells from a series of donors: Individual variation and modulation by bombesin analogs. Anat. Rec. 236:241-247.

21. Spindel, E. R., E. Giladi, P. Brehm, R. H. Goodman, and T. P. Segerson. 1990. Cloning and functional characterization of a cDNA encoding the murine fibroblast bombesin/GRP receptor. Mol. Endocrinol. 4:1956-1963.

22. Battey, J. F., J. M. Way, M. H. Corjay, H. Shapira, K. Kusano, R. Harkins J. M. Wu, T. Slattery, E. Mann, and R. I. Feldman. 1991. Molecular cloning of the bombesin/gastrin-releasing peptide receptor from Swiss 3T3 cells. Proc. Natl. Acad. Sci. USA. 88:395-399.

23. Corjay, M. H., D. J. Dobrzanski, J. M. Way, J. Viallet, H. Shapira, P. Worland, E. A. Sausville, and J. F. Battey. 1991. Two distinct bombesin receptor subtypes are expressed and functional in human lung carcinoma cells. J. Biol. Chem. 266:18771-18779.

24. Jensen, R. T., and D. H. Coy. 1991. Progress in the development of potent bombesin receptor antagonists. TIPS (Trends Pharmacol. Sci.). 12:13-19.

25. Trepel, J. B., J. D. Moyer, F. Cuttitta, H. Frucht, D. H. Coy, R. B. Natale, J. L. Mulshine, R. T. Jensen, and E. A. Sausville. 1988. A novel bombesin recepto antagonist inhibits autocrine signals in a small cell lung carcinoma cell line Biochem. Biophys. Res. Commun. 156:1383-1389.

26. Mahmoud, S., J. Staley, J. Taylor, A. Bogden, J.-P. Moreau, D. Coy, I Avis, F. Cuttitta, J. L. Mulshine, and T. W. Moody. 1991. [Psi ${ }^{13.14}$ ]bombesin analogues inhibit growth of small cell lung cancer in vitro and in vivo. Cancer Res. 51:1798-1802.

27. Carney, D. N., F. Cuttitta, T. W. Moody, and J. D. Minna. 1987. Selective stimulation of small cell lung cancer clonal growth by bombesin and gastrinreleasing peptide. Cancer Res. 47:821-825.

28. Sunday, M. E., J. Hua, H. B. Dai, A. Nusrat, and J. S. Torday. 1990 Bombesin increases fetal lung growth and maturation in utero and in organ culture. Am. J. Respir. Cell. Mol. Biol. 3:199-205.

29. King, K. A., J. Hua, J. S. Torday, J. M. Drazen, S. A. Graham, M. A. Shipp, and M. E. Sunday. 1993. CD10/neutral endopeptidase 24.11 regulates fetal lung growth and maturation in utero by potentiating endogenous bombesinlike peptides. J. Clin. Invest. 91:1969-1973.

30. Aguayo, S. M., W. E. Schuyler, J. J. J. Murtagh, and J. Roman. 1994 Regulation of lung branching morphogenesis by bombesin-like peptides and neutral endopeptidase. Am. J. Respir. Cell Mol. Biol. 10:635-642.

31. Polak, J. M., K. L. Becker, E. Cutz, D. B. Gail, L. Goniakowska-Witalinska, J. R. Gosney, J. M. Lauweryns, I. Linnoila, E. M. McDowell, Y. E. Miller, D. W. Scheuermann, D. R. Springall, M. E. Sunday, and G. Zaccone. 1993. Lung endocrine cell markers, peptides, and amines. Anat. Rec. 236:169-171.

32. Simerly, R. B., C. Chang, M. Muramatsu, and L. W. Swanson. 1990. The distribution of androgen and estrogen receptor mRNA-containing cells in the rat brain: an in situ hybridization study. J. Comp. Neurol. 294:76-95.

33. Spindel, E. R., M. D. Zilberberg, and W. W. Chin. 1987. Analysis of the gene and multiple mRNAs encoding human gastrin-releasing peptide (GRP): alternate RNA splicing occurs in neural and endocrine tissue. Mol. Endocrinol. 1:224-232.

34. Spindel, E. R., E. Giladi, T. P. Segerson, and S. R. Nagalla. 1993 Bombesin-like peptides: of ligands and receptors. Recent Prog. Horm. Res. 48:365-391.

35. Lebacq-Verheyden, A. M., G. Krystal, O. Sartor, J. Way, and J. F. Battey. 1988. The rat prepro gastrin releasing peptide gene is transcribed from two initiation sites in the brain. Mol. Endocrinol. 2:556-563.

36. Melton, D. A., P. A. Krieg, M. R. Rebagliati, T. Maniatis, K. Zinn, and M. R. Green. 1984. Efficient in vitro synthesis of biologically active RNA and RNA hybridization probes from plasmids containing a bacteriophage SP6 promoter. Nucleic Acids Res. 12:7035-7056.

37. Chirgwin, J. M., A. E. Przybyla, R. J. MacDonald, and W. J. Rutter 1979. Isolation of biologically active ribonucleic acid from sources enriched in ribonuclease. Biochemistry. 18:5294-5299.

38. Ausubel, F. M., R. Brent, R. E. Kingston, D. M. Moore, J. G. Seidman, J. A. Smith, and K. Struhl. 1987. Current protocols in molecular biology. John Wiley \& Sons, New York.

39. Spindel, E. R., M. D. Zilberberg, J. F. Habener, and W. W. Chin. 1986. Two prohormones for Gastrin-releasing peptide are encoded by two mRNAs differing by 19 bases. Proc. Natl. Acad. Sci. USA. 83:19-23.

40. Sausville, E. A., A. M. Lebacq-Verheyden, E. R. Spindel, F. Cuttitta, A. F. Gazdar, and J. F. Battey. 1986. Expression of the gastrin-releasing peptide gene in human small cell lung cancer. J. Biol. Chem. 261:2451-2457.

41. Watts, A. G., and L. W. Swanson. 1989. Combination of in in situ hybridization with immunohistochemistry and retrograde tract-tracing. Methods $\mathrm{Neu}$ rosci. 1:127-136.

42. Lorang, D., S. G. Amara, and R. B. Simersly. 1994. Cell-type specific expression of catecholamine transporters in the rat brain. J. Neurosci. 14:49034914.

43. Angerer, L. M., M. H. Stoler, and R. C. Angerer. 1987. In situ hybridization with RNA probes: an annotated recipe. In In Situ Hybridization, Application to Neurobiology. K. L. Valentino, J. H. Eberwine, and J. D. Barchas, editors Anonymous, editor. New York. 42-70.

44. Jaskoll, T. F., G. Don-Wheeler, R. C. Johnson, and H. C. and Slavkin 1988. Embryonic mouse lung morphogenesis and type II pneumocyte cytodifferentiation in serumless, chemically defined medium using prolonged in vitro cultures. Cell Differ. 24:105-118.

45. Wang, L.-H., D. H. Coy, J. E. Taylor, N.-Y. Jiang, S. H. Kim, J.-P Moreau, S. C. Huang, S. A. Mantey, H. Frucht, and R. T. Jensen. 1990. Desmethionine alkylamide bombesin analogues: A new class of bombesin receptor antagonists with potent antisecretory activity in pancreatic acini and antimitotic activity in Swiss 3T3 cells. Biochemistry. 29:616-622.

46. Davis, T. P., S. Crowell, J. Taylor, D. L. Clark, D. Coy, J. Staley, and T. W. Moody. 1992. Metabolic stability and tumor inhibition of bombesin/GRP receptor antagonists. Peptides (Tarryt.). 13:401-407.

47. Lloyd, R. V., and B. S. Wilson. 1983. Specific endocrine tissue marker defined by a monoclonal antibody. Science (Wash. DC). 222:625-630.

48. Lauweryns, J. M., L. Van Ranst, R. V. Lloyd, and D. T. O'Connor. 1987 Chromogranin in bronchopulmonary neuroendocrine cells. Immunocytochemical detection in human, monkey, and pig respiratory mucosa. J. Histochem. Cytochem. 35:113-118.

49. Ten Have-Opbroek, A. A. W. 1981. The development of the lung in mammals: an analysis of concepts and findings. Am. J. Anat. 162:201-219. 
50. Boyden, E. A. 1977. Development and growth of the airways. In Develop ment of the lung. W. A. Hobson, editor. Marcel Dekker, Inc., New York. 3-36.

51. Tyler, N. K., D. M. Hyde, A. G. Hendrickx, and C. G. Plopper. 1988 Morphogenesis of the respiratory bronchiole in rhesus monkey lungs. Am. J. Anat 182:215-223.

52. Baluk, P., J. A. Nadel, and D. M. McDonald. 1993. Calcitonin generelated peptide in secretory granules of serous cells in the rat tracheal epithelium Am. J. Respir. Cell Mol. Biol. 8:446-453.

53. Sunday, M. E., L. M. Kaplan, E. Motoyama, W. W. Chin, and E. R. Spindel. 1988. Biology of disease: Gastrin-releasing peptide (mammalian bombesin) gene expression in health and disease. Lab. Invest. 59:5-24.

54. Sunday, M. E., N. Choi, E. R. Spindel, W. W. Chin, and E. J. Mark. 1991. Gastrin-releasing peptide gene expression in small cell and large cell undifferentiated lung carcinomas. Hum. Pathol. 22:1030-1039.

55. Moody, T. W., D. N. Carney, F. Cuttitta, K. Quattrocchi, and J. D. Minna 1985. High affinity receptors for bombesin/GRP-like peptides on human smal cell lung cancer. Life Sci. 37:105-113

56. Heikkila, R., J. B. Trepel, F. Cuttitta, L. M. Neckers, and E. A. Sausville.
1987. Bombesin related peptides induce calcium mobilization in a subset of human small cell lung cancer cell lines. J. Biol. Chem. 262:16456-16460.

57. Kris, R. M., R. Hazan, J. Villines, T. W. Moody, and J. Schlessinger. 1987. Identification of the bombesin-receptor on murine and human cell by crosslinking experiments. J. Biol. Chem. 262:11215-11220.

58. Speirs, V., E. Bienkowski, V. Wong, and E. Cutz. 1993. Paracrine effects of bombesin/gastrin-releasing peptide and other growth factors on pulmonary neuroendocrine cells in vitro. Anat. Rec. 236:53-61.

59. Warburton, D., R. Seth, L. Shum, P. G. Horcher, F. L. Hall, Z. Werb, and H. C. Slavkin. 1992. Epigenetic role of epidermal growth factor expression and signalling in embryonic mouse lung morphogenesis. Dev. Biol. 149:123-133.

60. Heine, U. I, E. F. Munoz, K. C. Flanders, A. B. Roberts, and M. B. Sporn. 1990. Colocalization of TGF-beta 1 and collagen I and III, fibronectin and glycosaminoglycans during lung branching morphogenesis. Development (Camb.). 109:29-36.

61. Vigna, S. R., C. R. Mantyh, A. S. Giraud, A. H. Soll, J. H. Walsh, and P. W. Mantyh. 1987. Localization of specific binding sites for bombesin in the canine gastrointestinal tract. Gastroenterology. 93:1287-1295. 